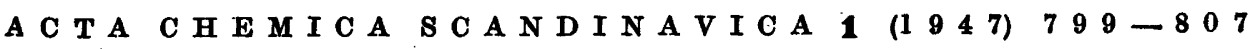

\title{
Determination of l-Aspartic Acid by Aspartase
}

\author{
ARTTURI I. VIRTANEN and ANTTILOUHIVUORI
}

Laboratory of the Foundation for Chemical Research, Biochemical Institute, Helsinki, Finland

Tnzymic methods have recently been applied to quantitative determination Dof certain amino acids. As far as we have noticed from the literature Virtanen and Laine ${ }^{1}$ were the first to use such a method (determination of $l$-aspartic acid by aspartase with dry preparation of Pseudomonas fluorescens or Bacterium propionici). The method which was strictly specific for this amino acid was employed as a macro method. Its accuracy was at the time not examined in detail. Virtanen and Laine applied somewhat later decarboxylase of lysine (Bacterium coli) to detection of lysine ${ }^{2}$. The method was very rough and chiefly employed for mere recognition of lysine.

During the last years Gale ${ }^{3}$ has successfully studied the amino acid decarboxylases of hundreds of bacteria and has worked out manometric methods for determination of lysine, tyrosine, arginine, histidine, glutamic acid, and ornithine. The methods are based on the high specificity of amino acid decarboxylases. Schales and Schales ${ }^{4}$ have used for determination of glutamic acid an enzyme solution prepared from squash. In the systematic investigations by Gale ${ }^{5}$ only the above mentioned six amino acids were decarboxylated by bacteria. Accordingly, application of the accurate and convenient micro method to estimation of other amino acids would not be possible. Virtanen and Laine ${ }^{6}$ have, however, earlier observed that Rhizobium leguminosarium decarboxylates also $l$-aspartic acid. The reaction is unfortunately slow and therefore not easily applicable as an analytical method. It is now under detailed investigation in this laboratory.

By means of aspartase $l$-aspartic acid can, however, be determined also in relatively small amounts with considerable accuracy. The method is outlined below. The reaction:

$$
l \text {-aspartic acid } \rightleftharpoons \text { fumaric acid }+\mathrm{NH}_{3}{ }^{*}
$$

* It is possible that water participates in the reaction and that the above formula indicates only the final products of the reaction and not its course. 
was noted by Quastel and Woolf ${ }^{7}$ with resting $B$. coli. Virtanen and Tarnanen brought the respective enzyme, aspartase, into solution from Pseudomonas fluorescens. The solution contains regularly also fumarase, the removal of which is difficult. Accordingly, the deamination of aspartic acid by the preparation depends except on the equilibrium of the reaction 1 also on that of the reaction 2:

$$
\text { fumaric acid }+\mathrm{H}_{2} \mathrm{O} \rightleftharpoons \text { malic acid }
$$

According to the equation of equilibrium:

$$
K=\frac{[\text { aspartat } \pm]}{[\text { fumarat }=]\left[\mathrm{NH}_{4}^{+}\right]}
$$

the deamination of aspartic acid is increased by the reaction 2 .

By precipitating the aspartase at $\mathrm{pH}$ 4.6 Virtanen and Erkama ${ }^{8}$ obtained a preparation which no longer caused the reaction 2 . This preparation gave the equilibrium constant $K_{37}=100$. In spite of the fact that the enzyme preparation did not form malic acid from fumaric acid in a solution without ammonia, it did form in experiments of long duration malic acid from aspartic acid as well as from fumaric acid in the presence of ammonia. Thus it seemed likely that the preparation contained besides aspartase an enzyme which catalyzed the reaction.

$$
l \text {-aspartic acid }+\mathrm{H}_{2} \mathrm{O} \rightarrow \text { malic acid }+\mathrm{NH}_{3}
$$

When after the war studies on this problem were again undertaken in this laboratory we did not succeed in liberating aspartase from fumarase by the precipitation described above. For this reason we have for the present been unable to re-examine the reaction 3 and to prepare fumarase-free aspartase for analytical determinations.

Although aspartase is not yet available in a form freed from other enzymes, and consequently, the equilibrium caused by the preparation used in every single case in unknown, it is, however, possible to use aspartase preparations for the quantitative determination of $l$-aspartic acid. It is only necessary to carry out by the side of the actual experiment a parallel one to which has been added approximately the same amount of aspartic acid as is found in the solution to be investigated. The amount of ammonia formed by the enzyme preparation from the known amount of $l$-aspartic acid can thus be determined. The determination must of course regularly include also a parallel experiment with enzyme preparation alone, which enables determination of possible formation of ammonia from the preparation itself. 
It should be mentioned that the equilibrium of the reaction is also affected by the magnesium salt content (Jacobsohn and Pereira ${ }^{9}$ ) of the solution which according to investigations in this laboratory may be attributed to the fact that when a phosphate buffer ( $\mathrm{pH} \mathrm{7)}$ is used ammonia is partly precipitated as ammonium magnesium phosphate and removed from the solution. Consequently, deamination of aspartic acid is promoted.

\section{EXPERIMENTAL}

As enzyme preparations we have in our experiments so far used both finely ground dry preparation of Pseudomonas fluorescens and cell-free extract prepared from that. The bacterium grows best in meat extract-pepton nutrient solution. A bacterial mass with highest aspartase activity was obtained by cultivating $P$ s. fluorescens in the following nutrient solution: 1 litre tap water, $8 \mathrm{~g}$ meat extract-pepton powder (Bacto Nutrient Broth Dehydrated. Difco Laboratories, U. S. A.), $3 \mathrm{~g} \mathrm{~K}_{2} \mathrm{HPO}_{4}$ and $1 \mathrm{~g} \mathrm{MgSO}_{4} \cdot 7 \mathrm{H}_{2} \mathrm{O}$. The $\mathrm{pH}$ was adjusted to $\mathrm{pH} 7$. The solution was heated for $\mathrm{l}$ hour in an autoclave at $120^{\circ}$, filtered clear while hot, the $\mathrm{pH}$ was again adjusted to 7 , and sterilized for $15 \mathrm{~min}$ at $120^{\circ} \mathrm{C}$. Cultivation of the bacterial mass was performed in an aluminium vat containing 200 litres nutrient solution, the layer of the solution was about $5 \mathrm{~cm}$ for securing sufficiently aerobic conditions. The vat was sterilized by heating and covered with greaseproof paper. The nutrient solution was inoculated with $10 \%$ of 3 days old culture of $P$ s. fluorescens (nutrient solution the same as above). The heavy inoculation prevented foreign infections during the short culture time $(48 \mathrm{~h})$. The temperature of cultivation was about $18^{\circ} \mathrm{C}$. The cells were separated from the solution by using a milk separator. The mass was washed twice in the centrifuge tubes with tap water. The salt-containing mass lying at the bottom of the tubes was discarded, only the cream-coloured surface layer was used. It was dried on porous plates. The dry mass was ground in a mortar to a dust-like powder. The mass maintains its full activity for at least half a year, probably for years. The bacterial mass can of course be produced even on a smaller scale by cultivating the bacteria in thin layers in glass flasks.

The cell-free aspartase solution was prepared by suspending $5 \mathrm{~g}$ finely ground bacterial mass in $100 \mathrm{ml}$ distilled water with some toluene and by allowing the suspension to stand with occasional shaking for 2 days at $37^{\circ} \mathrm{C}$. The suspension was centrifuged and the solution filtered through bacterial filter (Jena $17 \mathrm{G} 5$ auf 3 ).

Ammonia was determined in all experiments with the apparatus of Pucher. The method itself was modified so that ammonia was trapped in the receiver by $0.01 \mathrm{~N}$ $\mathrm{H}_{2} \mathrm{SO}_{4}$ and the excess of acid was titrated with $0.01 \mathrm{~N} \mathrm{NaOH}$ by using as indicator Tashiro's alcoholic solution of a mixture of methylene blue and methylene red. The solution to be analyzed was made alkaline in the distillation flask by Folin's solution (5 $\mathrm{g} \mathrm{Na}_{2} \mathrm{CO}_{3}+5 \mathrm{~g} \mathrm{NaCl}$ in $100 \mathrm{ml}$ water).

Tables 1 and 2 give two examples of our determinations of the liberation of ammonia from $l$-aspartic acid by aspartase preparations. The one was carried out with dried bacteria, the other with enzyme solution. The accuracy of the method in parallel experiments is illustrated by the examples. 


$$
\text { Experiment with dried bacteria }
$$

A sample of $500 \mathrm{mg}$ bacterium powder was placed in each of 6 test tubes, containing $5 \mathrm{ml}$ of $0.067 M$ phosphate buffer (pH 7.0) and $2 \mathrm{ml}$ toluene per tube. The powder was suspended carefully in the solution. To three of the tubes was added to each $10 \mathrm{ml}$ solution with $20.0 \mathrm{mg}$ neutralized $l$-aspartic acid, and to the other three respectively $10 \mathrm{ml}$ distilled water. The tubes were allowed to stand for 40 hours at $37^{\circ} \mathrm{C}$ with occasional shaking after which they were placed in ice water for interruption of the reaction. The results are given in Table 1.

Table 1. Formation of ammonia from l-aspartic acid by dry preparation of $P$ se udomonas fluorescens.

\begin{tabular}{|c|c|c|c|c|c|c|c|}
\hline Expt. & $\begin{array}{l}\text { Aspartic } \\
\text { acid, mg }\end{array}$ & $\begin{array}{l}\text { Aspartic } \\
\text { acid-N, } \\
\text { mg }\end{array}$ & $\begin{array}{c}0.01 \mathrm{~N} \\
\mathrm{H}_{2} \mathrm{SO}_{4} \\
\mathrm{ml}\end{array}$ & $\begin{array}{c}\mathrm{NH}_{3}-\mathrm{N} \\
\text { formed, } \\
\mathrm{mg}\end{array}$ & $\begin{array}{c}\mathrm{NH}_{3}-\mathrm{N} \\
\text { formed } \\
\text { from asp. } \\
\text { acid, mg }\end{array}$ & $\begin{array}{c}\mathrm{NH}_{3}-\mathrm{N} \\
\text { liberated } \\
\text { from asp. } \\
\text { acid-N, \% }\end{array}$ & $\begin{array}{l}\text { Found asp. } \\
\text { acid-N, \% } \\
\text { of added* }\end{array}$ \\
\hline I & & - & 17.20 & 2.408 & - & - & - \\
\hline II & - & - & 17.46 & 2.444 & - & - & - \\
\hline III & & - & 17.38 & 2.433 & - & - & - \\
\hline \multicolumn{4}{|c|}{ Average } & 2.428 & & & \\
\hline IV & 20 & 2.10 & 26.53 & 3.714 & 1.286 & 62.19 & 98.6 \\
\hline V & 20 & 2.10 & 26.96 & 3.774 & 1.346 & 64.09 & 101.6 \\
\hline VI & 20 & 2.10 & 26.79 & 3.751 & 1.323 & 63.00 & 99.9 \\
\hline \multicolumn{4}{|c|}{ Average } & 3.746 & & 63.09 & \\
\hline
\end{tabular}

Experiment with cell-free enzyme solution

The aspartase-containing solution prepared in the manner described above was pipetted into 9 test tubes, $5 \mathrm{ml}$ to each whereupon $5 \mathrm{ml}$ of $0.067 M$ phosphate buffer (pH 7.0) and $2 \mathrm{ml}$ toluene were added. To three of the tubes was added $20 \mathrm{mg} l$-aspartic acid in $2 \mathrm{ml}$ of water, to three again $60 \mathrm{mg} l$-aspartic acid in $6 \mathrm{ml}$ of water, while three were kept as controls without aspartic acid. Distilled water was added to each of the tubes to make the volume up to $22 \mathrm{ml}$. The tubes were kept for 7 days at $37^{\circ}$ after which they were placed in ice water and ammonia determination was made. The results are given in Table 2.

As can be seen from the tables the parallel experiments with equal amounts of aspartic acid give very concordant results. The accuracy of the ammonia determination decides how small amounts of $l$-aspartic acid can be determined by the method. By using the dry preparation the enzyme concentration can be raised so high that the equilibrium is reached in some hours. It is important that the reaction should have proceeded as far as possible before determination

* Calculated from the mean value of ammonia formed from aspartic acid. 
Table 2. Formation of ammonia from l-aspartic acid by the cell-free solution prepared from the dry preparation of $P s e u d o$ monas fluorescens.

\begin{tabular}{|c|c|c|c|c|c|c|c|}
\hline Expt. & $\begin{array}{l}\text { Aspartic } \\
\text { acid, mg }\end{array}$ & $\begin{array}{c}\text { Aspartic } \\
\text { acid-N, } \\
\text { mg }\end{array}$ & $\begin{array}{c}0.01 \mathrm{~N} \\
\mathrm{H}_{2} \mathrm{SO}_{4} \\
\mathrm{ml}\end{array}$ & $\begin{array}{c}\mathrm{NH}_{3}-\mathrm{N} \\
\text { formed, } \\
\quad \mathrm{mg}\end{array}$ & $\begin{array}{r}\mathrm{NH}_{3}-\mathrm{N} \\
\text { formed } \\
\text { from asp. } \\
\text { acid, mg }\end{array}$ & $\begin{array}{c}\mathrm{NH}_{3} \cdot \mathrm{N} \\
\text { liberated } \\
\text { from asp. } \\
\text { acid-N, \% }\end{array}$ & $\begin{array}{l}\text { Found asp. } \\
\text { acid-N, \% } \\
\text { of added* }\end{array}$ \\
\hline I & 0 & 一 & 7.22 & 1.011 & - & - & - \\
\hline II & o & - & 7.20 & 1.008 & - & - & - \\
\hline III & 0 & - & 7.17 & 1.003 & - & - & - \\
\hline \multicolumn{4}{|c|}{ Average } & 1.007 & & & \\
\hline IV & 20.0 & 2.10 & 16.05 & 2.247 & 1.240 & 59.05 & 100.0 \\
\hline V & 20.0 & 2.10 & 16.08 & 2.251 & 1.244 & 59.24 & 100.3 \\
\hline VI & 20.0 & 2.10 & 16.02 & 2.243 & 1.236 & -58.86 & 99.7 \\
\hline \multicolumn{4}{|c|}{ Average } & 2.247 & 1.240 & 59.05 & \\
\hline VII & 60.0 & 6.30 & 24.08 & 3.371 & 2.364 & 37.52 & 99.3 \\
\hline VIII & 60.0 & 6.30 & 24.55 & 3.437 & 2.430 & 38.57 & 102.1 \\
\hline IX & 60.0 & 6.30 & 23.94 & 3.348 & 2.341 & 37.22 & 98.3 \\
\hline \multicolumn{4}{|c|}{ Average } & 3.385 & 2.378 & 37.77 & \\
\hline
\end{tabular}

of ammonia because the quantities of ammonia will then be greater and the results accordingly more accurate. A difference of a few minutes in the duration of the experiment will no longer have any practical meaning and the quantity of aspartic acid in the control experiment needs not to correspond so exactly that in the solution to be investigated as would be necessary if the formation of ammonia were far from the maximum. This is clearly illustrated by Table 2 which shows the liberation of ammonia from $20 \mathrm{mg}$ and $60 \mathrm{mg}$ of aspartic acid when an equal quantity of enzyme solution and the same reaction time were used. In the former case $59.05 \%$ ammonia were split off, in the latter $37.77 \%$. In the latter case equilibrium was not yet attained.

The most convenient and rapid way of applying the described method to determination of $l$-aspartic acid is to employ finely ground bacterial mass as enzyme preparation. With enzyme solution possibly a somewhat higher accuracy is attained but before the solution can be used it should be concentrated since otherwise the time required is too long for practical analyses. Use of dried bacteria is naturally much more simple.

Aspartase can well be applied to determination of $l$-aspartic acid in protein hydrolysates and in $l$-aspartic acid-containing solutions in general, provided

* Calculated from the mean value of ammonia formed from aspartic acid. 
that they do not contain ammonia, fumaric or malic acids because these substances affect the equilibrium. Before determination of aspartic acid they must therefore be removed from the solution to be investigated: ammonia by distillation and the acids by extraction.

Experiments for determination of aspartic acid-N in casein by the method concerned

Two sorts of casein were available. Casein I (according to Hammarsten) was a preparation of the medical firm Orion, Helsinki, its total $\mathrm{N}$-content was exceptionally low, $\mathbf{1 4 . 6} \%$ of ash-free dry matter. Casein II (according to Hammarsten) was a preparation of Schering-Kahlbaum and its total $\mathrm{N}$-content was $15.70 \%$ of ash-free dry matter. The lower total $\mathrm{N}$-content of the former casein may be due to the manner of preparation. It has been ascertained in this laboratory that for instance, amide-nitrogen is partly split off from casein in an acid solution without any enzymes ${ }^{10}$.

For analyses $5 \mathrm{~g}$ of air-dry casein were hydrolyzed by boiling in $25 \mathrm{ml}$ of $37 \% \mathrm{HC}$ for 6 hours. The hydrolysate was diluted and made alkaline with $\mathrm{NaOH}$ (indicator phenolphthalein) and the ammonia $\mathrm{N}$ was removed in vacuo at $40-42^{\circ} \mathrm{C}$ by simultaneously leading air through the solution until the volume was reduced to about $1 / 3$ of the initial. The solution was neutralized with $\mathrm{HCl}$ to $\mathrm{pH} 7$ and made up to $300 \mathrm{ml}$ with water. Toluene was added in order to prevent infections. The hydrolysate thus prepared is fit for use only for two days at the highest. A sample of $5 \mathrm{ml}$ of this hydrolysate was used for each analysis.

$$
\text { Procedure }
$$

For experimental vessels we used $25 \mathrm{ml}$ test tubes closed with glass stoppers, An equal quantity of dried Ps. fluorescens powder was added to each test tube and besides toluene $1 \mathrm{ml}$. In order to facilitate the suspending of the test solutions 3 pure glass beads were placed to each tube. In every experiment the total volume of the solution was the same, $21 \mathrm{ml}$. The experiments 1-3, 10-12, 19-21, 28-30 are controls for determination of the $\mathrm{NH}_{3}-\mathrm{N}$ liberating from the bacterial mass. Each contained $160 \mathrm{mg}$ bacterial mass $+10 \mathrm{ml}$. $0.062 M$ (pH 7) phosphate buffer + $10 \mathrm{ml}$ water. - The experiments 4-6, 13-15, 22-24, and 31-33 show the formation of $\mathrm{NH}_{3}-\mathrm{N}$ from the bacterial mass $+l$-aspartic acid. The difference between the experiments with and without aspartic acid indicates that $\mathrm{NH}_{3}-\mathrm{N}$ has been formed from aspartic acid. Each test tube contained $160 \mathrm{mg}$ bacterial mass $+10 \mathrm{ml}$ buffer $+5 \mathrm{ml} \mathrm{H}_{2} \mathrm{O}+5 \mathrm{ml}$ neutral aspartic acid solution with $0.538 \mathrm{mg} l$-aspartic acid $\mathrm{N}$ (5.12 $\mathrm{mg}$ aspartic acid). - In the actual analyses, experiments 7-9, 16-18, 25-27, and 34-36, we used a quantity of casein hydrolysate, the aspartic acid content of which was according to the preliminary experiments known to be as nearly equal as possible to that of the control experiments. Since the percent of $\mathrm{NH}_{3}-\mathrm{N}$ formed in the controls is known, the amount of aspartic acid $\mathrm{N}$ present in the hydrolysate can be calculated on the basis of the $\mathrm{NH}_{3}$ estimations. Each experiment 
contained $160 \mathrm{mg}$ bacterial mass $+10 \mathrm{ml}$ buffer $+5 \mathrm{ml} \mathrm{H}_{2} \mathrm{O}+5 \mathrm{ml}$ hydrolysate. In the analyses of casein I the total $\mathrm{N}$ in the $5 \mathrm{ml}$ hydrolysate was $10,914 \mathrm{mg}$ and in those of casein II 11,850 mg. The time of aspartase action was in all experiments, both in controls and in actual ones, $120 \mathrm{~min}$. The tubes were kept in a water thermostat with temperature adjusted to $34^{\circ} \mathrm{C}$. The tubes were shaken vigorously at every quarter of an hour. Immediately after cessation of the reaction the contents of the tubes were washed to the $\mathrm{NH}_{3}$-distillation apparatus and $\mathrm{NH}_{3}$ was determined. Each of the four set of experiments including controls and actual experiments $(1-9,10-18,19-27$, and $28-$ 36) was carried out without interruption. This is necessary for the parallelism of the controls and the analyses.

Table 3. Determination of aspartic acid from the casein hydrolysate by dry preparation of $P s$. f $l$ uorescens. In experiments $I$ and $I I$ employed casein was a preparation of Orion, acc. to Hammarsten, in experiments III and IV of Schering-Kahlbaum acc. to Hammarsten. Duration of experiment $2 \mathrm{~h}$, temperature $34^{\circ} \mathrm{C}$.

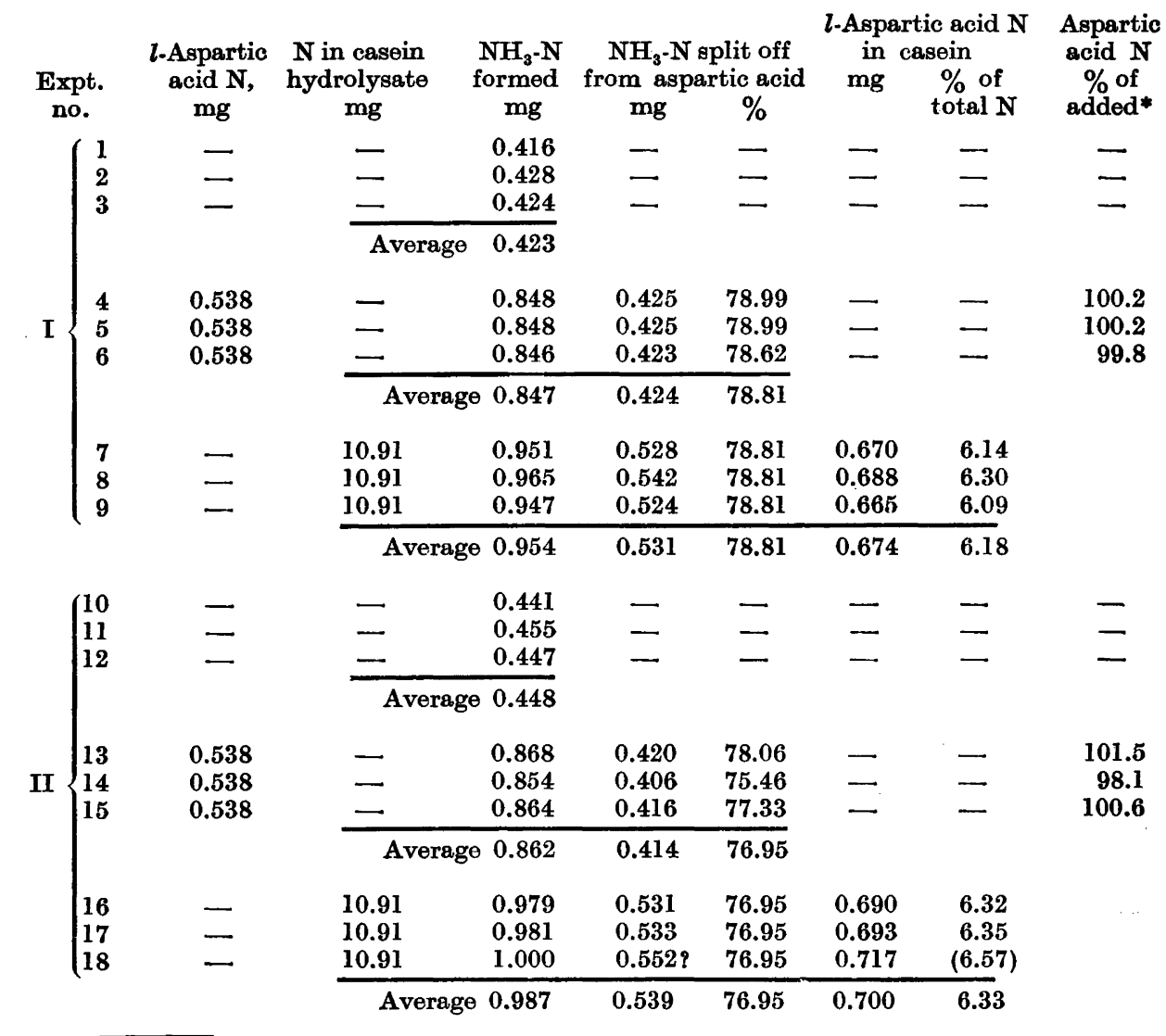

* Calculated on the basis of the average decomposition percentage of three decompositions. 


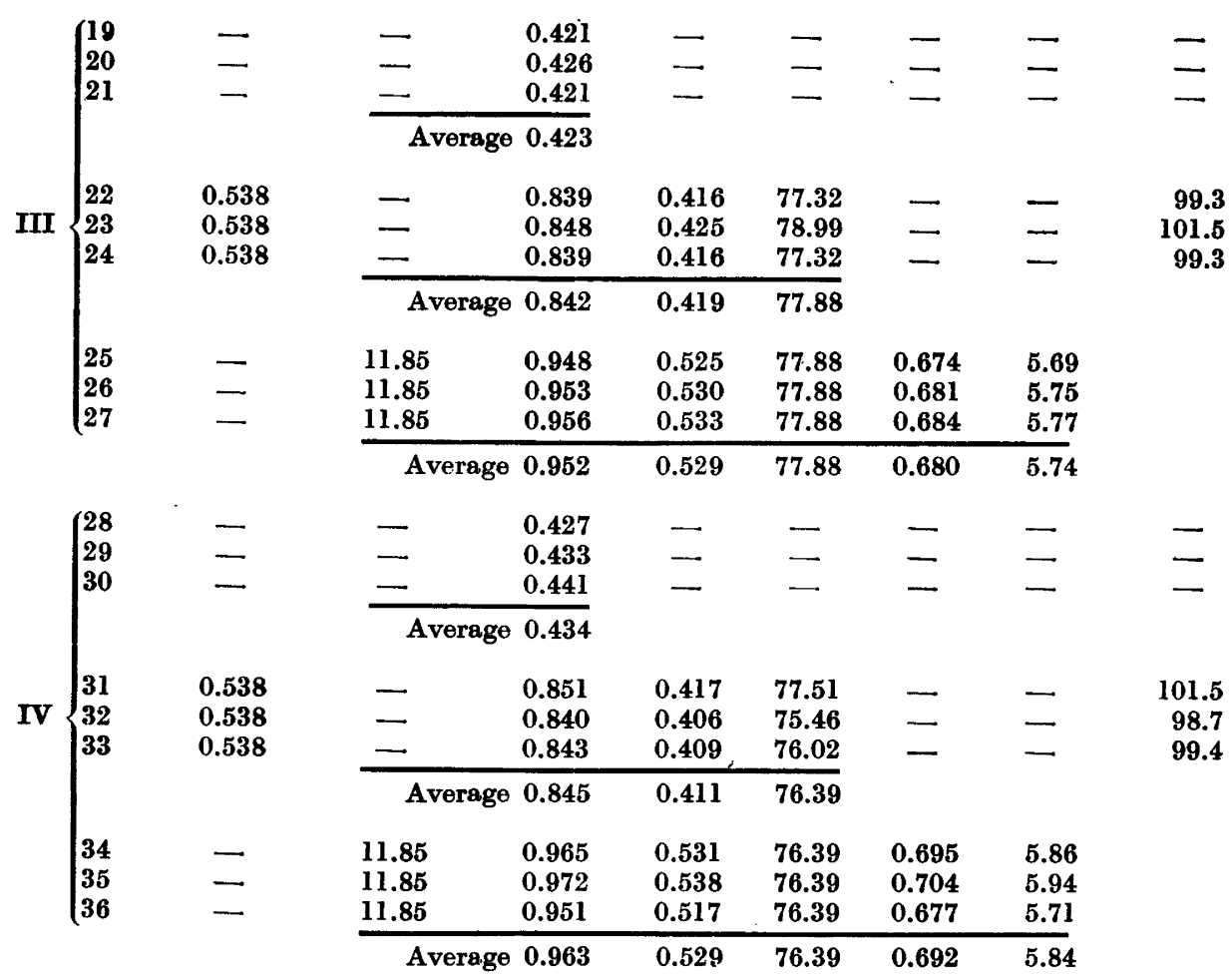

In the experiments (Table 3) the splitting off of ammonia has proceeded very far (76-79 \% of aspartic acid N). It can be seen from the values that in the parallel experiments of the same set only slight variations occur in the formation of ammonia from added aspartic acid. The same applies to the experiments with casein hydrolysate. Some greater deviations, as for instance, in the experiments 14 and 18 may be ascribed to the fact that the quantity of toluene in the pipette has been slightly smaller or greater than in the other experiments. Therefore it would be best to perform the analysis so rapidly that addition of toluene is unnecessary for preservation of the hydrolysate. Of particular importance to the application of the method is that all members of the same experiment are interrupted after an equally long period.

Other amino acids than $l$-aspartic acid did not split off ammonia under the experimental conditions. Especially $l$-glutamic acid was investigated in this respect. 


\section{SUMMARY}

Determination of $l$-aspartic acid is possible with considerable accuracy by the use of aspartase preparations. As the formation of ammonia through aspartase is exclusively restricted to $l$-aspartic acid, only determination of ammonia is required.

For enzyme preparations both finely ground dry preparation and cell-free enzyme solution of Pseudomonas fluorescens have been used. As the enzyme preparations employed have contained varying amounts of fumarase in addition to aspartase it is not possible to calculate a priori the equilibrium of the reaction. Determination of aspartic acid requires therefore three parallels.

1. Enzyme preparation + buffer solution $(\mathrm{pH} 7)$ for detection of ammonia formed from the preparation.

2. Enzyme preparation + buffer solution + a known quantity of $l$-aspartic acid. The difference between the experiments 1 and 2 expresses the quantity of ammonia liberated from aspartic acid.

3. Enzyme preparation + buffer solution + solution from which the aspartic acid is to be determined. On the extent of decomposition of aspartic acid in experiment 2 it is possible to calculate the amount of $l$-aspartic acid in the solution to be analyzed by means of the ammonia formed.

Casein (Schering-Kahlbaum, acc. to Hammarsten) with a $\mathrm{N}$-content of $15.70 \%$ of ash-free dry matter was found to contain $5.8 \% l$-aspartic acid $\mathrm{N}$ from total $\mathrm{N}$. Another casein preparation with only $14.6 \% \mathrm{~N}$ contained 6.2-6.3 \% $l$-aspartic acid $\mathrm{N}$ from total $\mathrm{N}$.

\section{REFERENCES}

1. Virtanen, A. I., and Laine, T. Nature 136 (1935) 756; Biochem. J. 33 (1939) 412.

2. Virtanen, A. I., and Laine, T. Suomen Kemistilehti B, 9 (1936) 7; B, 10 (1937) 2; Enzymologia 3 (1937) 266.

3. Gale, E. F. Biochem. J. 39 (1945) 46; Advances in Enzymol. 6 (1946) 1.

4. Schales, O., and Schales, S. S. Arch. Biochem. 11 (1946) 445.

5. Virtanen, A. I., and Laine, T. Suomen Kemistilehti B, 10 (1937) 2; Enzymologia 3 (1937) 266.

6. Quastel, J.H., and Woolf, B. Biochem. J. 20 (1926) 545.

7. Virtanen, A. I., and Tarnanen, J. Biochem. Z. 250 (1932) 13.

8. Virtanen, A. I., and Erkama, J. Nature 142 (1938) 954; cf. Erkama, J., and Virtanen, A. I., in Bamann, E., and Myrbäck, K., Die Methoden der Fermentforschung. Leipzig, 3 (1941) 2589.

9. Jacobsohn, K., and Pereira, A. Compt. rend. soc. biol. 120 (1935) 551.

10. Virtanen, A.I., and Hamberg, U. Acta Chem. Scand. 1 (1947) 847.

Received October 14, 1947. 